\title{
POMBAL, A MODERNIDADE E AS ORIGENS DA REFORMA DE ENSINO NA AMÉRICA PORTUGUESA E PORTUGAL
}

\author{
Alberto Damasceno \\ albertod@ufpa.br
}

\section{RESUMO}

Este artigo é parte de uma pesquisa mais ampla sobre a implantação do "Diretório dos Índios" de 1757 no Estado do Grão-Pará, à época governado pelo irmão do Marquês de Pombal, e busca discutir o papel que a reforma do ensino ali desencadeada teve no domínio luso da região, apresentando aspectos do contexto no qual a mesma se efetivou. No governo de Mendonça Furtado, irmão de Carvalho e Melo, entre os anos de 1751 e 1759, dá-se início a um amplo processo de transformações que culminaria, dentre outros acontecimentos, com o surgimento de escolas estatais que viriam a substituir o sistema jesuítico de educação elementar, antes mesmo da reforma do ensino deflagrada a partir de Lisboa. O instrumento legal que a subsidia é o "Diretório dos índios" de 1757, que pode ser considerado o mais importante documento de política educacional da história da América portuguesa naquele período.

Palavras-chave: Pombal; Reforma de ensino; Grão-Pará.

\section{ABSTRACT}

This article is part of a broader research on the establishment of the "Diretório dos Índios"of 1757in the State of Grão-Pará, which was ruled at that period by Marquês de Pombal's brother, and discusses the role ofeducation reform initiated there on Portuguese domination of the region, presenting aspects of the context in which it was accomplished. In the government of Mendonça Furtado, Carvalho e Melo's brother, between the years 1751 and 1759, it is initiated a broad transformation process which would culminate, among other events, with the emergence of state schools that would replace the Jesuit elementary education system, even before the reform of education deflagrated from Lisbon. The legal instrument that subsidizes it is the "Diretóriodos Índios" of 1757, which can be considered the most important document of educational policy in the history of Portuguese America at that time.

Keywords: Pombal; Education Reform; Grão-Pará

\section{RESUMÉN}

Este artículo esparte de una investigaciónmás amplia sobrela implantación del"Diretório dos Índios" de 1757 en el EstadodelGrão-Pará, en aquella época gobernado por elhermanodel Marqués dePombaly discuteel papelque la reformade la enseñanza allí desencadenada tuve en el dominioportugués enla región, presentando aspectos delcontexto en el quese llevó a cabo. En el gobiernodeMendonçaFurtado, hermano de Carvalhoe Melo, entre los años1751y1759, seinició unproceso de transformaciónque culminaría, entre otros eventos, con el surgimiento delas escuelas estatalesque reemplazaríael sistemajesuita dela educación elemental,incluso antes de lareforma de la enseñanzadesencadenadade Lisboa. El instrumentolegal que la subvencionaes el "Directorio de los indios" de 1757, que puede serconsideradoel documento de políticaeducativamás importantede la historia dela América portuguesaen ese momento.

Palabras clave:Pombal; Reformade la enseñanza; Gran Pará. 


\section{INTRODUÇÃO}

Dois movimentos históricos e contraditórios compõem a dialética da ação colonizadora de Portugal na Amazônia. De um lado, a separação entre Estado e Igreja em voga na Europa convive com a irrepreensível parceria entre a Coroa lusa e a Ordem jesuítica. De outro lado, os países ibéricos, corifeus das grandes conquistas marítimas durante os séculos XV e XVI, defrontam-se com profundas dificuldades econômicas enquanto outros países europeus experimentam importantes avanços em sua economia. Um momento decisivo para a superação dessa crise, Portugal viveu no século XVIII.

Este século passou para a história como um período de profundas transformações. A Europa Ocidental vivia a crise final do Feudalismo associada com o início da Revolução Industrial na Inglaterra. Enquanto isso, o sistema colonial europeu também vivia uma crise profunda. O Tratado de Utrecht, em 1713, marca o fim da hegemonia francesa e o início da hegemonia inglesa. Consolida-se o parlamentarismo na Inglaterra e começa a guerra dos sete anos, os Estados Unidos e o Haiti conquistam sua independência. Na França, agoniza o Antigo Regime e inicia-se a grande revolução burguesa enquanto acontece a reforma e ascensão de Rússia, Prússia e Áustria. A publicação das "Cartas Persas" por Montesquieu e das "Cartas Filosóficas" de Voltaire, ambas em 1734, do "O Espírito das Leis" por Montesquieu, em 1748, e da "Riqueza das Nações" de Adam Smith em 1776, difundem as ideias do iluminismo e da escola clássica em economia. Estes foram, dentre outros, fatos que contribuíram decisivamente para o início, no plano cultural, da formação do mundo ocidental contemporâneo.

Duas de suas características mais importantes são o mercantilismo, em franca expansão, e o iluminismo, que abriria uma extensa frente de combate ideológico com as igrejas católica e reformada; entretanto, esse processo de modernização ocorrido na península ibérica diferenciou-se em muito daquele que se deu no restante da Europa. Ao contrário de França, Itália, Inglaterra ou Alemanha, em Portugal e Espanha, este período transcorreu sem as mudanças essenciais que marcaram a nova face do mundo até então conhecido. Referindo-se especialmente à nação lusa, Francisco Falcon nos diz que "a reação do conservadorismo local, acirrada pelo ânimo contra-reformista, viria estancar todas as possibilidades de renovação e atualização. O moderno foi praticamente expulso e impedido a partir daí de penetrar no espaço mental lusitano". (FALCON, 1982, p. 151-2).

Tratava-se de um conflito de vida e morte, cujas metas alinhavam-se de acordo com os interesses em jogo. Tal processo transcorreu lenta e decididamente e atrasou os avanços da modernidade, que em Portugal só teria lugar a partir de Sebastião de Carvalho e Melo, ministro de D. José I. Ali, então, "fortalecem-se mutuamente, dialeticamente, desde o século XVI: Companhia de Jesus e Tribunal do Santo Ofício, de um lado; 'cristãos-novos' e 'estrangeirados', do outro. Nesse sentido é válido afirmar que, a rigor, a modernidade só irá ter lugar efetivamente no século XVIII, anunciando-se sob D. João V e desencadeandose, como processo, sob D. José I'. (FALCON, 1982, p. 152).

$\mathrm{O}$ combate sem tréguas às novas ideias vai ter na aristocracia sua principal interessada, em conjunto com a igreja, sua protagonista mais eficiente. Nesta guerra ideológica, processos identificados com a modernização das mentalidades, a exemplo da passagem da transcendência à imanência e da secularização, foram bastante prejudicados, tais os obstáculos políticos e ideológicos existentes.

Para comprovar essa afirmação, nada melhor talvez do que a própria fixação da escola conimbrense na perspectiva exclusiva da teologia, o completo repúdio a tudo que se associasse ao avanço do espírito matemático e natural, isto é, a uma outra verdade, distinta, não 
subordinada à revelada.(...). A secularização foi adiada e, por toda a parte, fez-se sentir, como nunca, a posição da igreja como aparelho ideológico dominante, permeando e controlando os demais de acordo com os princípios e interesses aristocráticos, assumindo um papel decisivo nos negócios de Estado. (FALCON, 1982, p.152-3).

Para agravar ainda mais o quadro descrito acima, em meados do século XVII, a situação econômica de Portugal era de extrema gravidade; "com a conjuntura internacional em plena fase de deflação, aguda entre 1640 e 1680, os portugueses veem-se a braços com o declínio dos réditos coloniais e o descenso de suas exportações em geral, complicados pelas lutas da Restauração, traduzindo-se tudo isso numa gravíssima crise financeira e monetária". (FALCON, 1982, p. 164).

Além de tudo, Portugal era um país cuja imagem em outras nações europeias não era das melhores. Maxwell nos diz que ele "tinha uma imagem triste no resto da Europa"

O escritor racionalista do século XVIII que precisasse de um estereótipo de superstição e atraso quase que invariavelmente recorria a Portugal. Voltaire resumia bem essa atitude. Ao escrever sobre o monarca português Dom João $\mathrm{V}$, com toda a sua riqueza em ouro, ele observou: "Quando queria uma festa, ordenava um desfile religioso. Quando queria uma construção nova erigia um convento. Quando queria uma amante, arrumava uma freira".(...). (MAXWELL, 1996, p. 17).

Na mesma passagem, uma citação de Charles Boxer comenta que o Portugal do século XVIII foi "mais dominado por sacerdotes do que qualquer outro país do mundo, com a possível exceção do Tibete”. (apud MAXWELL, 1996, p. 17).

GOMES, de certa forma, acaba concordando com estas visões ao afirmar referindo-se a Carvalho e Melo e António Verney, respectivamente o executor da reforma educacional e seu mentor intelectual — que "se ambos tivessem continuado a viver e a fazer carreira em Portugal, é muito provável que nenhum deles tivesse feito qualquer acção pela qual hoje merecesse ser recordado. Foi a estadia no estrangeiro que os 'iluminou' e lhes incutiu a ideia de que era sua missão 'iluminar' os seus concidadãos". (GOMES, 1995, p. 66).

Em síntese, a partir da segunda metade do século XVIII, enquanto algumas nações europeias já viviam a consolidação do capitalismo, outros países esforçavam-se para desenvolver uma política de reformas, buscando a modernização do Estado através suas monarquias. Tal processo esteve longe de ser tranquilo e, no caso português, assistiu-se a uma monumental tentativa de modernização administrativa, política, econômica e cultural que não deixou de apresentar profundas consequências e contradições, sobretudo se consideramos uma adaptação sofrível para o recém descoberto continente americano.

\section{O POMBALISMO}

O historiador português José Hermano Saraiva argumenta que comumente situa-se no reinado de D. Pedro II, em fins do século XVII, o estabelecimento da monarquia absoluta em Portugal, entretanto, questiona tal consideração, pois sustenta que "se existiu a oportunidade, não existiram as forças sociais indispensáveis para lhe dar realização". (SARAIVA, 1993, p. 230). No Estado luso algumas características foram garantidas sem, no entanto, consubstanciar uma verdadeira monarquia absolutista.

$\mathrm{O}$ fato de os reis passarem desde então a exercer o poder sem reunirem mais as Cortes não significa, porém, que o poder real se tornasse 
absoluto. Esse absolutismo verifica-se em relação ao terceiro estado, porque foi apenas ele que deixou de ser ouvido. Mas subsistiram os outros poderes que limitavam o poder real: o poder da nobreza e o poder do clero. A Inquisição manteve-se, muito tempo, impermeável à vontade régia. (SARAIVA, 1993, p. 231).

Na verdade, D. João V, sucessor de D. Pedro II, assim como este, não conseguiu governar sozinho. Havia muitos empecilhos para que suas vontades se impusessem sem oposições. Daí a importância das modificações que se seguiram à morte de $\mathrm{D}$. João $\mathrm{V}$ e à posse de D. José I. No raciocínio de Saraiva "a situação só se alterou na segunda metade do século XVIII, com o Governo pessoal do marquês de Pombal. A liquidação violenta da nobreza, a expulsão dos Jesuítas, a transformação da Inquisição em instrumento do Estado, a repressão violenta das manifestações populares, acabaram então com os verdadeiros limites ao poder absoluto do rei”. (SARAIVA, 1993, p. 232-3). Mesmo assim, Saraiva ainda nos adverte que "a filosofia política que serviu de suporte a essa acção foi a do absolutismo, mas a energia que a desencadeou foi a personalidade de Pombal". (SARAIVA, 1993, p. 233).

A era pombalina inaugura-se no ano de 1750, que inicia com a assinatura do Tratado de Madrid em 13 de janeiro. Em 31 de julho deste mesmo ano, morre D. João V e Dom José I assume o trono empossando como um de seus ministros Sebastião de Carvalho e Melo - posteriormente nomeado "Marquês de Pombal". Tal acontece através de Alvará Régio de 2 de agosto de 1750: "Havendo consideração á boa capacidade, com que Sebastião José de Carvalho e Mello dirigio em Dominios Estrangeiros os Ministerios, de que ElRei Meu Senhor e Pai o encarregou: Hei por bem nomea-lo Ministro e Secretario d'Estado dos Negocios Estrangeiros e Gente de Guerra;..."

Desde então, inicia-se uma nova fase de desenvolvimento do Estado luso. Portugal tinha um rei soberano e três Conselhos: o Ultramarino, a Mesa de Consciência e Ordens e o da Fazenda. Abaixo destas instâncias, situavam-se os Vice-Reis ou Governadores Gerais de suas Colônias. Deste modo, logo no início da ocupação do território brasileiro, nossa colônia tinha um governo geral sobre as Capitanias (governadas por capitães-mores) e submisso ao Rei de Portugal.

Quando Sebastião de Carvalho e Melo é nomeado ministro - por influência da rainha regente de Portugal, Maria Ana de Áustria - o Poder executivo do reino português organizava-se em três pastas: Ministério do Reino, Marinha e Ultramar, dirigido por Diogo de Mendonça; Ministério da Guerra, dirigido por Pedro da Motta e o Ministério dos Negócios Estrangeiros dirigido por ele. Sua capacidade de articulação e influência logra a destituição de Diogo de Mendonça, em agosto de 1756, através de Decreto Real e, posteriormente, sua consequente nomeação como um poderoso Ministro de Estado, o que o tornava senão de direito, pelo menos de fato, o homem forte de Portugal.

Assim, no primeiro ano da posse de Pombal no elevado cargo, definiamse claramente as prioridades do novo governo, em sua política mercantil e imperial. Os produtos vitais do sistema comercial luso-brasileiro, açúcar, fumo e ouro, seriam protegidos por disposições legais e defendidos os interesses estabelecidos. Enérgica tentativa foi feita para racionalizar a máquina arrecadadora do tributo básico - o quinto real. Os devedores coloniais foram protegidos contra execuções sumárias. Casas de inspeção foram criadas para regular os preços dos produtos fundamentais da colônia. E, o que é básico para todo conceito do futuro do território americano: a segurança da colônia seria garantida por sua população - o 
que não poderia ser feito mediante a imigração de massas européias, porém pela libertação e europeização dos indígenas. (MAXWELL, 1995, p. 32).

Naquele período, a economia portuguesa encontrava-se em crise devido a diversos fatores, em especial ao declínio da produção mineral brasileira. O reforço dos vínculos coloniais, visando a retomada do crescimento do Império era fundamental, apesar do ideário liberal já em voga na Europa. Pombal, visando retomar o crescimento econômico, implanta várias medidas: decreta o recolhimento de no mínimo cem arroubas de ouro por ano para a metrópole e o monopólio da Real Extração no Distrito Diamantino, restringe os privilégios da nobreza e do clero, reorganiza as frotas navais e os portos, cria o Banco Real, proíbe a exportação de moedas e cria as Companhias Gerais de Comércio do GrãoPará e Maranhão e de Pernambuco e Paraíba.

No que tange às relações com a Inglaterra, o Marquês busca autonomizar-se tentando uma via própria de crescimento ou, como diz Ferrnando Novais, "desenvolve-se na segunda metade do século XVIII todo um esforço de recuperação econômica (...), que necessariamente envolvia um recuo da presença dominante dos interesses ingleses". (NOVAIS, 1983, p. 122).

\section{O PROCESSO DE COLONIZAÇÃO DA AMÉRICA}

Durante o século XVII a palavra que melhor caracteriza as ações portuguesas em termos da colonização americana é "crise". Como dito anteriormente, a mentalidade arcaica que persistia nos marcos do seu pensamento dominante, o declínio da produção mineral em sua principal colônia, a perda de controle sobre o tráfico negreiro e o domínio - retrógrado - ainda persistente da nobreza e do clero colocaram Portugal no contrafluxo do desenvolvimento europeu. Por outro lado, mantinha-se a estreita ligação com a nação inglesa, detentora da quase submissão lusa aos seus desígnios. Novais argumenta que "somente por um momento, no meado do século, durante a Guerra dos Sete Anos, a crise originada pelo "pacto de família", e o confronto generalizado entre Inglaterra e França, envolveria de novo Portugal. A mesma diretriz salvou-o novamente: a pertinaz procura da neutralidade, a hesitação diante das opções, e finalmente a mantença da aliança inglesa. (NOVAIS, 1983, p. 30).

Carvalho e Melo é o mais importante protagonista de uma grande crise, daí a polêmica que envolve seu nome quando se trata de tecer qualquer consideração sobre Portugal durante seu governo. Ele governa em um momento de cisão efetiva na cristandade portuguesa. De um lado está a parcela da nobreza articulada com os jesuítas. De outro, também uma parcela da nobreza, mas aliada à burguesia mercantil. $\mathrm{O}$ grande confronto ideológico se constituiu na luta entre os fisiocratas regalistas - defensores da terra como única fonte de riquezas, cuja face religiosa em Portugal, era D. Tomas de Almeida, oratoriano e futuro Diretor Geral de estudos, secundado pelos oratorianos todos - e o projeto transnacional dos jesuítas.

Seu governo, para muitos um momento grandioso e inimitável, foi permeado de contradições. Em que pese seu discurso vinculado à idéia de modernidade, competência administrativa e idoneidade, historiadores portugueses como João Lúcio d'AZEVEDO o caracterizam como opressivo, incapaz e corrupto:

Não offerece a historia moderna exemplo de mais oppressivo regimem colonial, nem de tão prolixa e minuciosa legislação economica. Ia o ministro accumulando privilegios, interdicções, penalidades, que 
seguidamente, por novas disposições, explicava, abolia, ampliava. N'este confuso labirinto de alvarás, cartas régias, e regulamentos, quizeram muitos ver a manifestação de um bem reflectido systema de governo, quando o seu auctor só de estranhos privilegios, e da mais requintada tyrannia soube lançar mão,...Graças a tal systema, poderam enricar os favorecidos, tomando os despojos de alheias fortunas, emquanto a maioria da população tinha de suportar inauditos vexames. (AZEVEDO, 1994, p. 71-2).

O plano econômico pombalino, de incentivo à agricultura e ao comércio nas colônias de além-mar, irá encontrar no Estado do Grão-Pará um de seus focos principais, tanto pela necessidade de assegurar em mãos lusas aquela imensa faixa de terra como pela enorme potencialidade de exploração que o primeiro ministro antevia. Um dos caminhos para consegui-lo, traçou-se na área da instrução pública.

\section{O DESENVOLVIMENTO DA INSTRUÇÃO}

Refletindo sobre as características do Estado moderno Chartier argumenta que seu desenvolvimento, assim como o de uma "religião mais individual", tem sua base sobre uma condição: "a maior familiaridade com o escrito. Cada vez mais e não obstante as resistências, é ele que transmite as vontades da autoridade pública, que alimenta as devoções da intimidade muitas vezes fundamentadas na leitura. Para aqueles que não têm, ou ainda não têm, acesso à experiência suprema da oração puramente mental e do diálogo direto com Deus, o livro é uma ajuda necessária". (CHARTIER, 1991, p. 25). Neste, e noutros sentidos, indiscutivelmente, o século XVIII representa um marco definitivo na história da educação. Diz Luzuriaga sobre ele:

O século XVIII é o século pedagógico por excelência. A educação ocupa a primeira plana [sic] nas preocupações dos reis, pensadores e políticos.(...)

Filosoficamente, é o "Século das Luzes", "da Ilustração", da Aufklärung. (...). Todos coincidem no reconhecer a supremacia da razão.

Politicamente, é, na primeira parte, a época do absolutismo e, mais concretamente, do "despotismo esclarecido", que deseja o bem do povo, mas sem o povo. (...).

Pedagogicamente, é o século de instrução sensorialista e racionalista, do naturalismo e do idealismo na educação, assim como da educação individual e da educação nacional. (LUZURIAGA, 1981, p. 149).

Algumas características, levantadas por Luzuriaga, a respeito da educação no século XVIII, aplicam-se decididamente ao processo que se desenvolvia no âmbito do Estado português naquele momento. De um lado, dava-se o "desenvolvimento da educação estatal, da educação do Estado, com maior participação das autoridades oficiais no ensino, de outro, a iniciação do laicismo no ensino, com a substituição do ensino de religião pela instrução moral e cívica". Destaque-se ainda, "a organização da instrução pública em unidade orgânica, da escola primária à universidade". (LUZURIAGA, 1981, p. 150-1).

Quanto à educação estatal, ou processo de secularização do ensino, "cresce de ponto [sic] com a progressiva intervenção do Estado na educação, até vir a converter-se em função essencial do Estado, ocasionando aquilo que chamamos de educação pública estatal, isto é, educação subordinada aos fins do Estado". (LUZURIAGA, 1981, p. 151).

Chartier também corrobora esta leitura histórica destacando a abordagem de Ariès: 
Para compreender a maneira nova como se traça, do século XVI ao XVIII, a fronteira entre os domínios do privado e as competências das autoridades públicas e comunitárias, Philippe Ariès sugeriu examinar desse ponto de vista as três evoluções fundamentais que transformam então as sociedades do Ocidente: o novo papel do Estado, que cada vez mais interfere em questões que durante muito tempo não eram de sua alçada; as Reformas religiosas, tanto as protestantes como a católica, que exigem dos fiéis uma devoção mais interior, mais íntima; por fim, os progressos do saber ler e do saber escrever, graças aos quais o indivíduo pode se emancipar dos antigos elos que o prendiam à comunidade numa cultura da fala e do gesto. (CHARTIER, 1991, p. 22).

Para Luzuriaga, o rei da Alemanha, Frederico Guilherme I, é criador de um decreto (de 1717) que "aplica, pela primeira vez num grande Estado, o princípio da obrigatoriedade escolar, ao dispor 'que de futuro, em todos os lugares onde houver escolas, devem os pais ser obrigados, sob castigo rigoroso, a mandar a elas os filhos, mediante pagamento de dois dreier como retribuição semanal"”. (LUZURIAGA, 1981, p. 151). Semelhante à situação portuguesa, a educação em França também estava nas mãos das congregações religiosas, em especial dos Jesuítas e dos Irmãos da Doutrina Cristã. Diz o citado autor que "foi motivo para comêço da educação pública estatal em França a supressão da Companhia de Jesus em 1762. Haviam os Jesuítas chegado a absorver o ensino secundário e superior, e contra êles se haviam levantado muitas vozes, em diferentes setores do reino". (p. 153). Compayré é citado para confirmar a antipatia que desfrutavam os membros da Companhia que, "sob pretexto de servir o Papa, pretendia reger o mundo; que açambarcava a religião, da qual fazia propriedade; que governava os reis pelos confessores que lhes dava, quando não os suprimia pela mão dalgum fanático; que substituía a idéia de pátria por uma espécie de cosmopolitismo religioso". (LUZURIAGA, 1981, p. 153-4).

Neste sentido, Portugal foi o mais pioneiro, criando escolas de ler e escrever sob controle estatal já em 1758, através de Alvará que confirma o Diretório de 1757 de Mendonça Furtado, e expulsando os jesuítas em 1759.

Para alguns historiadores, à supressão do sistema educacional jesuítico, Pombal interpôs uma reforma. Para outros, ele protagonizou, na verdade, uma paralisação das atividades educacionais através da adoção de medidas efêmeras e ineficazes. Sem entrar no mérito das divergências de opinião sobre os resultados das Reformas educacionais de Sebastião de Melo, é mister afirmar que na época compreendida entre os séculos XVI e XVIII passa a existir um grande desenvolvimento do exercício da leitura e da escrita na Europa e em alguns outros países. Para Chartier "nos países reformados e nas nações católicas, nas cidades e nos campos, no Velho e no Novo Mundo, a familiaridade com a escrita progride, dotando as populações de competências culturais que antes constituíam apanágio de uma minoria". (CHARTIER, 1991, p. 116).Por outro lado, é lícito afirmar que as diferenças essenciais existentes entre o processo de surgimento das escolas estatais em Portugal e em França são decorrência das suas situações econômicas e políticas.

Se nos dois países a escola se conforma estatal e obrigatória, na França, em fins do século XVIII, ela é gratuita e radicalmente leiga enquanto no Grão-Pará, em meados do mesmo século, ela é paga e inicialmente leiga. Portugal não teve naquele período, ao contrário de outros países, um ensino plenamente estatal. Mesmo após a expulsão dos jesuítas, e de outras ordens, as instituições dirigentes do ensino foram comandadas por 
religiosos com muito prestígio junto a Roma e ao governo luso ${ }^{2}$. Apesar de tudo, em Portugal, a segunda metade do século XVIII é decisiva para a instrução do povo e das elites.

\section{A INTERVENÇÃO POMBALINA NO GRÃO-PARÁ E A CONVERSÃO DE CONSCIÊNCIAS}

$\mathrm{Na}$ América portuguesa, a primeira experiência pedagógica nasce dos religiosos, tributários da função de cristianizar os índios. Entretanto, a tarefa de conversão dos gentios, longe de se constituir em uma resposta adequada aos propósitos da Coroa ou em uma atividade moral e espiritual própria ao mundo do conquistado, transporta para o plano dos missionários um "absoluto poder" sobre o estado geral dos índios. A forma de vida dos gentios, adequava-se ao desígnio de fornecer e conduzir "os gêneros pertencentes" aos religiosos. Em vez de somente levar-lhes à experiência da transcendência, os missionários cumpriam pari passu o propósito de encobrir e conservar o poder secular religioso.

A ausência de uma linguagem comum e unificadora, que pudesse unir os gentios, os colonos e o governo, fora substituída por uma "gíria" que divorciava a relação entre esses mundos. Para o governador Mendonça Furtado, era usada com tirania, como tutela das religiões, produzindo como consequência a "total ruína das fazendas dos moradores e da conservação do Estado". (apud MENDONÇA, 1963, p. 64-7). Neste sentido, a palidez da doutrina cristã operada pela Companhia se encontrava na precária comunicação da "língua portuguesa, porque isto é inteiramente contra a tirania do seu governo". (apud MENDONÇA, 1963, p. 66). Como se percebe, a língua portuguesa era um símbolo morto, à custa de que:

São os ditos índios educados para explicarem Deus dizendo Tupana Açu = Deus grande; e os Santos, suas imagens e verônicas Tupana Mirim = Deus pequeno; e isto que eles dizem que é um modo de explicar, por não haver na tal língua a palavra Santo, sempre dado por elemento de religião a uma gente silvestre, lhes forma uma idéia de muitos deuses, o que é totalmente defendido e oposto à verdadeira fé que nos ensina a Igreja Católica (...) a errada máxima de se ensinar a tal gíria barbarizando a palavra santo, assim como tem barbarizado infinitas palavras portuguesas que se acham inseridas nela (...) (apud MENDONÇA, 1963, p. 66-7).

Assim, os padres missionários, foram considerados como objeto de reprovação e de influência moralmente negativa:

- Conseguindo os Regulares que S.M. lhes desse, não só o governo espiritual das aldeias, mas também o temporal e político, se persuadiram logo que estas aldeias todas eram suas;

- Persuadiram-se as Religiões que aquelas aldeias eram suas, porque são governadas por um missionário que nelas reside, o qual batiza, faz casamentos, dispensa nos impedimentos, administra absoluta despoticamente todo o espiritual;

- Administram mais com um governo absoluto e despótico todo o temporal, sem que das suas injustiças e violências haja para quem recorrer, porque no dito governo não há ordem ou forma de proceder, e em consequência não se admite apelação ou recurso para tribunal algum.

- Como os Regulares se viram senhores absolutos desta gente e das suas povoações; como se forma fazendo senhores das maiores e melhores 
fazendas deste Estado, vieram a absorver naturalmente todo o comércio, assim dos sertões como o particular desta cidade, e vieram a cair os direitos reais e dízimos e em consequência a cair o Estado, sem remissão. (apud MENDONÇA, 1963, p. 70-2).

Pretendendo despertar a Corte para o perigo das ações missionárias no que tange ao risco que essas traziam ao completo domínio luso na Amazônia, Mendonça Furtado se impõe ante os padrões religiosos e nega "o Corpo Poderoso" da Companhia de Jesus, visando frear o privilégio dos seus membros enquanto

(...) senhores dos índios, e por consequência senhores de tudo, e eles pobres, miseráveis, sem remédio humano e perseguidos das mesmas Religiões, estabelecendo-se cada vez mais sobre a sua ruína;...

Como cada Religião desta aspira a ter o comércio universal deste Estado, não tratam de outra coisa mais do que ver o modo por que hão de arruinar umas às outras, valendo-se todas dos meios que as podem conduzir àquele fim;

Como neste Estado não é rico o que tem muitas terras, senão aquele que tem maior quantidade de índios, tanto para a cultura como para a extração de drogas dos sertões (...) (apud MENDONÇA, 1963, p. 76-7).

O objetivo de isolá-los foi conquistado definitivamente em 1759 e aconteceu em seguida ao alvará de reforma dos "estudos menores" de Pombal ${ }^{3}$, imputando para os religiosos o amargo sabor do desterro.

Em 1758 o poder temporal dos jesuítas foi eliminado e o sistema diretor de controle indígena, designado por Mendonça Furtado para o Pará e Maranhão, tornou-se aplicável a toda a América lusa. A 3 de setembro de 1759 o governo português decretou a proscrição e a expulsão da Companhia de Jesus de todo o Império, proibindo qualquer comunicação verbal ou escrita entre os jesuítas e os súditos portugueses. Em 1760 o navio Nossa Senhora de Arrábia, da Companhia do Pará, levou os últimos jesuítas do Maranhão para o exílio. (MAXWELL, 1995, p. 44).

Por outro lado, o cenário de fundo dos acontecimentos na Amazônia portuguesa, à época identificada com o Estado do Grão-Pará e Maranhão, configurava-se num confronto que contribuía para o enfraquecimento do sistema colonial.

De um lado, o desenvolvimento irreversível da revolução industrial inglesa exigia cada vez mais a abertura dos mercados ultramarinos consumidores de produtos manufaturados; por outro lado, a política de autonomização e desenvolvimento econômico dos países ibéricos ia cada vez mais dificultando a penetração dos produtos ingleses nos mercados do ultramar pelas vias metropolitanas. O resultado dessa coincidência de tendências divergentes tinha necessariamente de fazer com que os interesses do industrialismo inglês se orientassem no sentido da ruptura do pacto colonial, removendo-se o intermediário das metrópoles. (NOVAIS, 1983, p. 123).

Em outro âmbito, influenciado por uma nova concepção da relação entre Estado e Igreja, corolário do complexo iluminismo europeu e pelas contendas insolúveis em torno 
do controle sobre as aldeias entre os colonos e os Jesuítas, Pombal expulsa aqueles religiosos das colônias ultramarinas portuguesas. Do Grão-Pará se vão quarenta deles, em 1759 , ao mesmo tempo em que o Estado lhes confisca uma fortuna em bens acumulados ${ }^{1}$.

O interesse do Estado na libertação dos índios chocava-se com os dogmas filosóficos fundamentais da política protecionista dos jesuítas. Além do mais, as atividades de Mendonça Furtado ao norte logo puseram em evidência que, ao tirar a mão-de-obra indígena do controle dos missionários, a libertação também ameaçava solapar a fonte básica da riqueza e da predominância do jesuíta no Amazonas, De fato, a secularização parecia significar — como em 1734 já previra o magistrado Francisco Duarte dos Santos - que "as missões ficariam apenas na memória”. Os participantes do grande complexo missionário-mercantil centrado na Companhia de Jesus, no Pará e Maranhão, não admitiriam facilmente sua relegação ao status de meros conselheiros espirituais. (MAXWELL, 1995, p. 33).

Ainda para Maxwell, Mendonça Furtado:

(...) achava que para a prosperidade na Amazônia seria essencial privar os jesuítas do "poder absoluto" que o controle da mão-de-obra indígena e a posição estratégica de suas missões lhes davam tanto no comércio, quanto no contrabando. Visando consolidar a autoridade secular, estimular o comércio e prover mão-de-obra africana em condições mais acessíveis do que as proporcionadas pelos traficantes privados, parecia-lhe uma solução lógica a criação de uma companhia "com fundamentos sólidos". Um suprimento abundante de negros tornaria desnecessária a escravidão indígena, reduziria a influência jesuíta e proporcionaria a mão-de-obra indispensável ao trabalho da terra e ao desenvolvimento do comércio. E isto, por sua vez, aumentaria a arrecadação real e ajudaria a financiar o novo sistema defensivo e a garantia as fronteiras dos domínios portugueses. (MAXWELL, 1995, p. 34).

São evidentes os sinais de que o conflito vivenciado por Jesuítas e pombalinos nos limiares da expulsão daqueles das terras de Portugal não se limitaram a divergências de ordem administrativa ou de política econômica, mas constituía-se num profundo corte ideológico que deixaria marcas indeléveis por todo o reino e ultramar durante os tempos seguintes. Liquidar o "Estado" jesuítico dentro dos domínios lusos; assumir, em lugar dos inacianos, o domínio espiritual (ideológico) das aldeias, e confiscar os inúmeros bens acumulados pelos jesuítas foram algumas fortes causas para a sua expulsão pela Coroa portuguesa.

Machado (1989, p.80) identifica no longo período de governo de Carvalho e Melo duas fases distintas, embora integradas. Na primeira, até 1760, dominaram os problemas de reorganização comercial, enquanto na segunda, reforçam-se os privilégios mercantis, a cobrança de impostos e há uma política de fomento industrial na metrópole e de fomento agrícola na colônia americana. Naquela, em pleno governo de seu meio-irmão Mendonça Furtado, a autora assevera que "podem ser identificadas duas medidas de impacto na colônia. A primeira, foi a criação das companhias de comércio, acompanhada da dissolução da Mesa do Bem Comum; a segunda foi a expulsão dos jesuítas (...)" (MACHADO, 1989, p 80). Em seguida à extinção dos estabelecimentos dessa Ordem, 
Mendonça Furtado decide criar um novo modelo de escola que serviria de modelo para a reforma que seu irmão propagaria por todo o reino português.

\section{A REFORMA POMBALINA DA INSTRUÇÃO}

Nos seus "prolegômenos dos estudos secundários: o ensino elementar", Banha de Andrade atesta que "ninguém ignora que as categorias do ensino elementar, secundário e superior, no que concerne à dimensão da quantidade específica, não tinham existência legal, escalonada, no tempo em que as Universidades cumpriam o programa que o seu nome abarcava etimologicamente". (ANDRADE, 1978, p. 1).

No prefácio de seu livro "As reformas pombalinas da instrução pública", Laerte Ramos de Carvalho assevera que "no conjunto das manifestações espirituais do século XVIII português, as reformas pombalinas da instrução pública ocupam lugar de excepcional significação". (CARVALHO, 1978, p. 1). E ainda: "As reformas da instrução pública encerram, mais do que um plano pedagógico, uma filosofia política, em função da qual se definem, em seus traços mais característicos, a fisionomia do período histórico de que são expressiva manifestação”. (CARVALHO, 1978, p. 3).

Para essas reformas da instrução em Portugal e na América portuguesa Laerte Ramos de Carvalho ajuíza que

colaboraram homens desiguais na mentalidade: ao lado de um até então obscuro opositor da Universidade de Coimbra, o brasileiro João Pereira Ramos de Azeredo Coutinho, o Bispo Manuel Cenáculo Villas Boas; ao lado do médico judeu, o estrangeiro Ribeiro Sanches, os oratorianos da Real Casa de Nossa Senhora das Necessidades de Lisboa, ao lado de Seabra da Silva, com sua manhosa indiscrição, o leal Bispo reformador da Universidade. as reformas pombalinas foram, desta forma, muito mais um denominador comum de opiniões do que a expressão de uma vontade única que se impusesse, de cima para baixo, intransigentemente, feita e acabada. (CARVALHO, 1978, p. 2).

Não restam dúvidas de que Pombal era um homem experiente, formado na diplomacia inglesa e bem relacionado. No âmbito intelectual suas influências iluministas em Portugal originaram-se, segundo Maxwell, "de Martinho de Mendonça de Pina e Proença (1693 - 1743), que tentou adaptar a Portugal algumas das teorias de Locke; os escritos do cristão-novo Dr. Jacob de Castro Sarmento (1692 - 1762), que introduziu em Portugal as idéias newtonianas, e os trabalhos do Dr. Antonio Nunes Ribeiro Sanches (1699 - 1783), também cristão-novo e conhecido de Pombal em Viena". (MAXWELL, 1996, p. 10).

Outra frente de influências sobre Carvalho e Melo, podemos encontrar nos Oratorianos, grandes adversários dos jesuítas no debate pedagógico. Para Maxwell, eles foram os grandes promotores das ciências naturais, tendo introduzido em Portugal as idéias de Francis Bacon, Descartes, Gassendi, Locke e Antonio Genovesi. também enfatizaram a importância da língua, da gramática e da ortografia portuguesa, que acreditavam devessem ser estudadas diretamente e não através do latim. (MAXWELL, 1996, p. 14).

Importância consagrada é a de Luís António Verney (1713-1792), que para Gomes (1995) "foi sem dúvida, o maior teórico do iluminismo em Portugal”(p. 65).Sua mais conhecida obra, o "Verdadeiro Método de Estudar...", surgiu em Nápoles, em 1746, sem o nome do autor, pois, como o mesmo previu, a polêmica em torno do livro foi grande e apaixonada. Entretanto, Verney não tratou somente de questões pedagógicas, escrevendo 
alhures "propostas para uma reforma global da sociedade - da Igreja e do Estado inserindo-se algumas dessas propostas no melhor espírito do Iluminismo europeu da época". (GOMES, 1995, p. 72).

Concordando, diz Carvalho que "as reformas pombalinas da instrução pública constituem expressão altamente significativa do iluminismo português". (CARVALHO, 1978, p. 25). Para ele, "um de seus objetivos, a remodelação dos métodos educacionais vigentes, pela introdução da filosofia moderna e das ciências da natureza em Portugal, era a preocupação constante de algumas das mais expressivas figuras intelectuais da época". (CARVALHO, 1978, p. 5), o que a caracteriza como um passo decisivo na conformação de uma nova cultura dominante naquele país.

Por seu turno, Banha de Andrade adverte-nos para o fato de que esta reforma não foi totalmente pombalina, mas ao contrário, processou-se em duas fases distintas sob a batuta de dois mentores diferenciados. A primeira fase, ele considera iniciar-se a partir da expulsão dos Jesuítas em 1759 e extinguir-se com o começo da segunda fase, que tem seu marco na transformação da Universidade de Coimbra em 1771 e na transferência da direção dos estudos menores para a Real Mesa Censória, em 1772.

Na direção da primeira fase - segundo ele erroneamente chamada de pombalina - não estava o "Marquês de Pombal" porque Sebastião de Carvalho e Melo ainda não tinha recebido tal título e porque então, "o homem forte da instrução, quer na metrópole, quer no ultramar" naquele momento foi D. Tomás de Almeida, nomeado director-geral dos Estudos em 6 de julho de 1759. Na segunda fase, sim, Carvalho de Melo — já Marquês interviu decididamente através de D. Frei Manuel do Cenáculo Villas-Boas, presidente da Real Mesa Censória e reformador dos estudos na congregação da Ordem Terceira. (Cf. ANDRADE, 1982, p. 591). Caeiro é mais um dos que evidencia duas fases na chamada reforma pombalina do ensino. Diz ele:

$\mathrm{Na}$ verdade, a reforma pombalina do ensino elementar e secundário compreendia duas fases distintas, que não têm sido devidamente salientadas em sua efetiva diferenciação: a primeira, que vai da expulsão dos jesuítas (1759) até a remodelação orgânica da Universidade de Coimbra e transferência dos Estudos Menores para a Real Mesa Censória (1771-1772), e uma segunda fase, que decorre entre este último termo e o final do reinado de D. José I. (CAEIRO apud CARVALHO, 1978, p. 212).

Se há um momento chave em todo o processo de implantação da Reforma de ensino de Carvalho e Melo, este é o da expulsão dos jesuítas. O trabalho realizado pela Companhia, desde a sua fundação até sua extinção, garantiu-lhe, com larga margem, o corifeu de instituição educativa por excelência. Seu crescimento quantitativo, monumental mesmo para os cânones da cristandade dos séculos XVI, XVII e XVIII, é digno de citação:

Na altura da morte de Inácio de Loiola, ocorrida em 31 de julho de 1556, dos 40 Colégios, cuja criação ele havia aprovado, 35 estavam em funcionamento. Tinha então a Companhia cerca de 1.000 membros, que exerciam o seu ministério em 110 Casas, distribuídas por 13 Províncias (...)

(...) em 1615, (...), os jesuítas eram mais de 13.000 e dirigiam 372 Colégios. Quando foi extinta, em 1773, a Companhia contava 23.000 membros e dirigia, na Europa, 546 Colégios e 148 Seminários e, fora da 
Europa, 123 Colégios e 48 Seminários, ou seja, um total de 865 estabelecimentos de ensino (GOMES, 1995, p. 33-4).

Creio que esses dados dão ideia do grau da responsabilidade de Pombal no que tange à reorganização do ensino na Metrópole e suas colônias. Além de repor o que estava desaparecendo junto com a Ordem jesuítica fazia-se mister para o ministro, lograr alguns avanços na direção da modernidade tardia em seu país.

Por outro lado, este é um processo que, como já foi dito antes, não começa somente durante o consulado pombalino, mas alguns anos antes. Carvalho confirma esta tese dizendo que "esta renovação pedagógica, inspirada nos ideais e problemas da filosofia moderna, não é uma manifestação exclusiva do período pombalino; ela se inicia no reinado de D. João V e prolonga-se, sem solução de continuidade, e através de vicissitudes diversas, no governo de D. Maria I'. (CARVALHO, 1978, p. 26).

Para o historiador português Rómulo de Carvalho, o grande adversário ideológico dos Jesuítas foi Verney:

O declínio da preponderância da Companhia de Jesus no ensino, nesta primeira metade do século XVIII, começava a desenhar-se com nitidez embora a Companhia reagisse animosamente às investidas da Congregação do Oratório. O seu grande inimigo, porém, não foram os oratorianos nem qualquer instituição prestigiada ou grupo ideológico cujos esforços se somassem para atacarem a poderosa organização jesuítica. O grande inimigo, nesta metade do século, foi um único homem que, isoladamente, lançou um desafio à Companhia de Jesus chamando-a à liça no campo do ensino, com as armas que possuia que eram a sua vastíssima cultura e o seu 'ódio ideológico' à instituição de Santo Inácio. Trata-se de Luís António Verney, um homem que simboliza a transformação social em curso, quer se aplauda quer se repudie. (CARVALHO, 1986, p. 406).

No prólogo do livro de Carvalho, Francisco da Gama Caeiro também observa o importante papel que (direta ou indiretamente) tiveram os jesuítas no que tange à reforma. Ali ele assevera que

o episódio da expulsão dos jesuítas de Portugal e de seus domínios, com a consequente abolição do ensino jesuítico, é a pedra de toque para a maioria dos historiadores, educadores e comentaristas das reformas pombalinas de ensino. Apologistas exaltados das realizações jesuíticas de ensino e defensores ou detratores da política pombalina recaem igualmente no momento da expulsão como ponto de referência inicial, decisivo e até único de um amplo e complexo período histórico de ensino. (Caeiro In CARVALHO, 1978, p. 20-1).

Para além de compreender que a expulsão da Companhia foi fator decisivo nas mudanças que adviriam, creio que é fundamental perceber que a implantação das reformas pombalinas do ensino menor têm sua gênese em territórios mais remotos que o solo europeu. Quanto a essas mudanças, Andrade considera como decisivo

em primeiro lugar (no quadro pedagógico que a Corte pretendeu instaurar, em substituição do prevalente, até a extinção da Companhia de Jesus), a instituição de escolas para os índios, no momento da 
transformação das aldeias em vilas e ensaio da administração preconizada no Diretório. Tudo começou, pois, com a nomeação, por ordem régia de 19 de abril de 1751, do Governador e Capitão-general do Estado do Maranhão [e Grão-Pará], Francisco Xavier de Mendonça Furtado, para residir em Belém do Pará, e do Tenente-coronel Luís de Vasconcelos Lobo, para Governador da Capitania do Maranhão. (ANDRADE, 1978, p. 7).

Diante do que afirma Banha de Andrade, um fato é inegável: o de que a primeira iniciativa régia em relação a este nível de ensino (o elementar), neste período, deu-se justamente no Estado do Grão-Pará, quando Mendonça Furtado determinou que os missionários não fossem mais responsáveis pela educação dos índios. Esta tarefa passaria a ser dos "diretores de aldeias", de acordo com o "Diretório que se deve observar nas povoações dos índios do Pará e do Maranhão enquanto sua majestade não mandar o contrário", norma pioneira que veio a dar origem à reforma pombalina dos estudos menores.

\section{CONSIDERAÇÕES FINAIS}

Nem sempre o que é propugnado em um determinado momento da história é realizável neste mesmo momento ou nos períodos que lhe seguem. Tomo como exemplo as obras dos grandes pensadores iluministas que tinham como objeto primordial a transformação das mentalidades, no sentido de tornar o homem capaz de se guiar pela própria razão, tornando-se autônomo e independente de qualquer autoridade exterior. Tal ideal vem a consubstanciar-se como concretude e ação cotidiana apenas alguns séculos depois. Isto, no entanto, não diminui a importância e o caráter essencialmente inovador das obras dos seus mais ilustres defensores.

Bárbara Freitag há muito já nos alertava a respeito de um time lag entre a promulgação e a efetivação de uma lei quando argumenta que "Se a lei é expressão dos interesses de uma classe ou coalizão de classes, esses interesses, materializados nos objetivos e fins de ensino só podem ser analisados na realidade e avaliados de acordo com o seu maior ou menor desvio das atenções originais, vários anos depois". (FREITAG, 1986, p. 59).

É a partir dessa linha de raciocínio que vejo o papel de Pombal, de seu irmão Mendonça Furtado e do Diretório de 1757. Muito embora seus objetivos não tenham sido alcançados e, com efeito, sua edição tenha resultado em um relativo fracasso, as reflexões que continha e as propostas que lançava, caracterizavam-no francamente como um marco no processo de assunção por parte do Estado português, da responsabilidade em relação à educação, definindo uma nova relação deste com o problema da instrução dos índios e, posteriormente, de toda a colônia.

As escolas então criadas, o são por iniciativa do Estado. Elas se constituem numa imposição estatal, fruto de sua necessidade, de um projeto político de colonização, por conseguinte, de aculturação. É aqui que Portugal antecede França, mas de um modo particular. Não é a República que descobre o valor da escola para a formação de uma nova cidadania, mas a Monarquia que revela sua face Absoluta. Furtado não era somente um governador senão também, o coordenador da comissão de demarcação das terras de Portugal na Amazônia colonial, em conflito latente com a Espanha. Cabia basicamente a ele garantir que importantes nacos da possessão lusa na América não escorregassem para o domínio espanhol. 
O acúmulo de funções não era coincidência. À missão de governar o grande Estado imbricava-se inseparável a de demarcar suas fronteiras com terras da Espanha e a estas duas, aliava-se a de garantir ocupação portuguesa nos espaços disputados e conquistados. $\mathrm{Na}$ ausência de portugueses em quantidade suficiente para efetivar tal ocupação, valeu-se Mendonça Furtado dos nativos amazônidas, estes, experientes no trato com a terra e com seus vizinhos. Entretanto, uma característica tinha de ser inoculada nestes indivíduos para que eles cumprissem bem a função de "portugueses": saber falar a "Língua do Príncipe".

Daí, a estreita ligação entre a expansão portuguesa no vale amazônico, corolário da política pombalina de exploração de matérias-primas e incentivo ao comércio na região, e as iniciativas de um ensino pretensamente sistemático e intensivo da língua portuguesa no Estado do Grão-Pará.

Este não era o projeto dos Jesuítas, empenhados que estavam em difundir e implantar uma igreja supranacional através da constituição de missões sob sua jurisdição. Daí o violento conflito, cujo vitorioso - mesmo que parcial - foi Sebastião de Carvalho e Melo.

Em relação ao conflito entre a Coroa portuguesa - representada no Grão-Pará e Maranhão pelo seu governador - e os Jesuítas, podem-se arrolar várias causas. Entretanto, uma divergência de fundo salta aos olhos quando se investiga de forma mais acurada os interesses econômicos em jogo naquele tempo e espaço: o domínio da força de trabalho. Tanto o próprio Mendonça Furtado, quanto José Caeiro ou mesmo Vieira - protagonista privilegiado (e insuspeito) no século anterior, são unânimes em confirmar esta tese.

Do ponto de vista político, os jesuítas possuíam além do poder espiritual, o poder temporal (governo) das aldeias; na economia, possuíam empreendimentos prósperos baseados na extração de matéria-prima e comércio, pecuária e engenhos; ideologicamente obtinham a confiança dos nativos graças a seu competente trabalho de catequese, além de dominar a "língua geral" (nheengatu), o que lhes garantia excelente fluxo de comunicação e informações. Um dos instrumentos mais eficazes de sua ação era, portanto, a escola onde curumins, filhos dos principais ${ }^{5}$ e mesmo de colonos, todos juntos, aprendiam como deveria ser a vida do bom cristão.

Todo esse "paraíso" desmorona com a intervenção direta de Carvalho e Melo por meio do governo de Mendonça Furtado, sobretudo com a edição do Diretório de 1757. A partir de então, os religiosos passam a exercer apenas o poder espiritual, pois o governo das aldeias, mais tarde elevadas à categoria de "lugares" ou "vilas", passa às mãos de um Diretor indicado pelo governo. Em termos de economia, o Estado pugna pelo estímulo à agricultura e ao comércio, que atinge seu ponto máximo com a criação da Companhia Geral em 1755. No plano ideológico e dos costumes, o documento estimula casamentos inter étnicos, premia os que falam o português, cria escolas independentes das jesuítas e nomeia as aldeias com nomes de cidades portuguesas, transformando a face do Estado português na Amazônia.Se o sistema diretoriano de escolarização não passou de um arremedo do monumental modelo jesuítico, seu projeto de implantação do uso da "Língua do Príncipe" obteve pleno êxito, integrando de uma vez por todas o imenso território amazônico à Pax portuguesa.

\section{REFERÊNCIAS}

ANDRADE, António Alberto Banha de. A reforma pombalina dos estudos secundários no Brasil. São Paulo: EDUSP/Saraiva, 1978. 
ANDRADE, António Alberto Banha de. Contributos para a história da mentalidade pedagógica portuguesa. Lisboa: Imprensa Nacional - Casa da Moeda, 1982.

AZEVEDO, João Lúcio d'. Estudos de história paraense. Belém: SECULT, 1994 [1893] (Série Lendo o Pará, vol. 19).

CARVALHO, Laerte Ramos de. As reformas pombalinas da instrução pública. São Paulo, Saraiva / EDUSP, 1978.

CARVAlHO, Rómulo. História do ensino em Portugal Lisboa: Fundação Calouste Gulbenkian, 1986.

CHARTIER, Roger (org.). História da vida privada, 3: da Renascença ao Século das Luzes. São Paulo: Companhia das Letras, 1991.

DECRETOS e leys de D. José, o I - 1750-1762.

FALCON, Francisco José Calasãs. A época pombalina: política econômica e monarquia ilustrada. São Paulo: Ática, 1982.

FREITAG, Bárbara. Escola, Estado e sociedade. São Paulo: Moraes. $6^{\mathrm{a}}$ ed. 1986.

GOMES, Joaquim Ferreira. Para a história da educação em Portugal: seis estudos. Porto: Porto Editora, 1995.

LUZURIAGA, Lorenzo. História da educação e da pedagogia.13a ed.. São Paulo: Cia Ed. Nacional, 1981.

MACHADO, Lia Osório. Mitos e realidades da Amazônia brasileira no contexto geopolítico internacional (1540-1912). 2 vol. Tese de Doutorado. Barcelona: Departamento de Geografia Humana da Universidade de Barcelona, junho de 1989. (mimeo.).

MAXWELL, Kenneth R.. A devassa da devassa. A inconfidência mineira: BrasilPortugal - 1750-1808. Rio de janeiro: Paz e Terra, 1995.

MAXWELL, Kenneth. Marquês de Pombal: paradoxo do iluminismo. Rio de Janeiro, 1996.

MENDONÇA, Marcos Carneiro de. O pensamento da metrópole portuguêsa em relação ao Brasil. Separata da revista do Instituto Histórico e Geográfico Brasileiro. Vol. 257 - outubro/dezembro - 1962. Rio de Janeiro: IHGB, 1963.

NOVAIS, Fernando. Portugal e Brasil na crise do antigo sistema colonial (1777-1808). $2^{a}$ ed.. São Paulo: Hucitec, 1983.

SARAIVA, José Hermano. História de Portugal. Mem Martins: Publicações EuropaAmérica, 1993. 


\section{NOTAS}

1. Ver Manuel Nunes Dias. “A Companhia Geral do Grão-Pará e Maranhão” p.175-189.

2. Ver trabalho de Guilherme Braga de Cruz: Direitos e deveres do Estado na educação. Lisboa: 1952.

3. Para comprovar a atribuição da ruína de Portugal aos jesuítas ver o Decreto de 28 de junho de 1759 de D. José I, do qual extraí o trecho a seguir: "Desejando eu não só reparar os mesmos estudos para que não acabem de cair na total ruína a que estão próximos mas ainda restituir-lhes aquele antecedente lustre que fez dos portugueses tão conhecidos na república das letras antes que os mesmos religiosos [jesuítas] se intrometessem a ensina-los com sinistros intentos e infelizes sucessos"... (Decretos e leys de D. José, o I 1750-1762).

4. "Verdadeiro Método de Estudar para ser útil à República e à Igreja, proporcionado ao estilo e necessidade de Portugal. Exposto em várias cartas escritas pelo R. P. XXX, Barbadinho da Congregação de Itália, ao R. P. XXX, Doutor da Universidade de Coimbra".

5. Apesar de ser um termo geralmente utilizado para designar os chefes das tribos contactadas, há estudos evidenciando que "na maioria das vezes os 'principais' não são líderes dos índios descidos, mas pessoas com trânsito entre os colonos brancos e autoridades do governo colonial. Liderança fundada no domínio da língua portuguesa e da 'língua geral' e no tino comercial para essa atividade". (ALMEIDA: 97, 327).

Recebido: novembro/16 Aprovado: dezembro/16 